\title{
Home Leaving Trajectories in Canada: Exploring Cultural and Gendered Dimensions
}

\author{
Ellen M. Gee \\ Department of Sociology and Anthropology \\ Simon Fraser University \\ Vancouver, British Columbia \\ Barbara A. Mitchell \\ Department of Sociology and Anthropology \\ and Gerontology Programs \\ Simon Fraser University \\ Vancouver, British Columbia \\ Andrew V. Wister \\ Department of Sociology and Anthropology \\ and Gerontology Programs \\ Simon Fraser University \\ Vancouver, British Columbia
}

\begin{abstract}
In this exploratory study, we profile variations in home leaving, home returning, and home staying behaviour among four ethnocultural groups in Canada British, Chinese, Indian, and South European. Data collected in a 1999-2000 survey of 1,907 young adults (ages 19-35) residing in the Vancouver area are used. Our principal foci are ethnocultural and gendered aspects of home leaving trajectories, specifically: ages at home leaving and returning, and reasons for home leaving, home returning and home staying. Special attention is paid to returners/boomerangers, given an increasing overall trend in home returning in Canada. We find that: (a) both ethnocultural origin and gender are important determinants of home leaving trajectory, (b) there is a distinct (but far from tidy) difference between European-origin and Asian-origin groups in home leaving trajectory, (c) British-Canadians leave home at the youngest ages and Indo-
\end{abstract}


Ellen M. Gee, Barbara A. Mitchell and Andrew V. Wister

Canadians at the oldest ages, (d) the main reason for home leaving is independence for British-Canadians; schooling for Chinese-Canadians, and marriage for Indo-Canadians, (e) among all four groups, home returners leave home initially at younger ages and, with the exception of Indo-Canadian young men, who typically leave home for school, and (f) gender differences in home leaving trajectory are larger among the Chinese and Indo-Canadians than among persons of European origins. Overall, we conclude that the theorized trend of the individualized family life course holds for only some ethnocultural groups in Canada. We conclude with suggestions for future research directions on the topic of ethnicity and the home leaving life course transitions.

Key Words: Home leaving, home staying, home returning, boomerang young adults, ethnic differences, gender differences, movement trajectories

\section{Résumé}

Dans cette étude préliminaire, nous donnons le profil de plusieurs comportements relatifs au fait de quitter la maison, d'y retourner et d'y rester de quatre groupes ethnoculturels au Canada, notamment les Britanniques, les Chinois, les Indiens et les ressortissants du sud de l'Europe. On s'est servi de données recueillies lors d'un sondage effectué en 1999-2000 auprès de 1907 jeunes adultes (âgés de 19 à 35 ans) vivant dans la région de Vancouver. Nous étions particulièrement intéressés par les aspects ethnoculturels et ceux qui tiennent compte du rôle des hommes et des femmes dans les trajectoires qui les mènent à quitter la maison, plus précisément à quel âge ils la quittent et y reviennent, quelles sont les raisons qui les poussent à partir, à y revenir et à y rester. Une attention toute spéciale est accordée aux enfants boomerang (ceux qui reviennent après avoir quitté la maison) vu que cette tendance se manifeste de plus en plus au Canada. Nous avons trouvé que : a) l'origine ethnoculturelle et le sexe sont des déterminants importants dans la trajectoire de quitter la maison, b) il existe une différence (quoique pas nette) entre les ressortissants des groupes d'origine européenne et ceux d'origine asiatique dans cette démarche, c) les Canadiens d'origine britannique sont les plus jeunes à quitter la maison et ceux d'origine indienne sont les plus âgés à partir, d) le principal motif de vouloir partir est le désir d'indépendance pour les Canadiens d'origine britannique, les études pour ceux qui sont d'origine chinoise et le mariage pour ceux qui sont d'origine indienne, e) parmi les quatre groupes, ceux qui reviennent sont partis à un âge plus jeune, à l'exception des jeunes Canadiens d'origine indienne qui partent pour faire des études, et f) les différences entre les trajectoires des hommes et des femmes sont plus importantes chez les Canadiens d'origine chinoise et indienne que chez les Canadiens d'origine européenne. Nous en sommes arrivés à la conclusion que la tendance théorique d'une vie de 
Home Leaving Trajectories in Canada: Exploring Cultural and Gender Dimensions

famille individualisée n'est valable que pour certains groupes ethnoculturels au Canada. En guise de conclusion, nous proposons de possibilités de recherches sur l'ethnicité et les transitions relatives au fait de quitter la maison.

Mots-clés : quitter la maison, rester à la maison, retourner à la maison, jeunes adultes boomerang, différences ethniques, différences entre les sexes, trajectoire de mouvement

\section{Introduction}

Socio-cultural and economic change in North American society has had significant consequences for the family life course transitional behaviours of young adults. In particular, young adults are leaving the parental home at later ages, and often for "independence" rather than marriage (Boyd and Norris, 2000; Ravenera, Rajulton and Burch, 1995). It is also apparent that home leaving is not necessarily a one-time event. Indeed, $27 \%$ of all Canadian young adults aged 19-35 return home at least once as "boomerang kids," a phenomenon that appears to be historically unprecedented (Mitchell, Wister and Gee, 2000).

As a result of these changing patterns of home leaving, intergenerational coresidence is becoming more common. Using 1996 Canadian census data, Boyd and Norris (1999) report that 33\% of unmarried men aged $20-34$ and $23 \%$ of unmarried women 20-34 live at home. Data for 1981 are $26 \%$ and $16 \%$, respectively. These figures translate into a $27 \%$ increase in the rate of coresidence for men aged $20-34$, and a $44 \%$ increase for similarly aged women over this 15 year period.

While these broad trends indicate that important changes have occurred in home leaving patterns, they mask the diversity that exists within Canadian society. High levels of immigration, particularly from Asian societies, have contributed to ethnic diversity and a multiplicity of family types that may or may not fit "modal" patterns of life course behaviours. Ethnic minority families may retain "traditional" aspects of their cultural heritage (such as family-centeredness and strict gender-role ideology) that can affect life course behaviours (Goldscheider and Goldscheider, 1988). For example, leaving home for marriage might be more acceptable than leaving to seek independence in some ethnic groups than others. Also, young women may be subject to stricter expectations than young men among some ethnic groups. 
Ellen M. Gee, Barbara A. Mitchell and Andrew V. Wister

Research to date on coresidence and its component parts - home staying, home leaving and home returning - reveals evidence of a pervasive cultural dimension. Boyd (2000) finds that ethnic origin is one of the strongest determinants of the propensity of young adults to coreside in the parental home. In particular, Greek, Italian, Balkan, Portuguese, South Asian, Chinese, other South and Southeast Asian, Arab, West Indian, and Jewish groups exhibit the highest rates of coresidence. Furthermore, young women from these groups have higher rates of coresidence than their male age peers, which is opposite to the general pattern observed among unmarried young adults in Canada (Boyd and Norris, 2000). In the U.S., Goldscheider and Goldscheider (1999) similarly observe that Blacks, Hispanics, and Asians tend to leave home at older ages than Whites, thereby displaying higher rates of coresidence. Canadian research on home returning among Francophones, Anglophones and "other" language groups documents that, compared to English-speaking young adults, Francophones are more likely to return home than are Anglophones. Yet members of "other" language groups are more likely to return home than Anglophones (Mitchell et al., 2000). Together these findings substantiate that ethnocultural background is a central factor influencing home leaving trajectories.

This growing body of literature highlighting ethnic differences in living arrangements tends to use broad "brush strokes." We lack a detailed examination of the experience of specific Canadian ethnic groups that also incorporates analyses of multiple living arrangements and their transitions. For example, Boyd (1998), using Canadian census data, only examines patterns of staying at home, since the census does not include information on age of home leaving and age at returning. Furthermore, with regard to ethnocultural membership, the census asks questions about ancestors' ethnic origin(s), rather than ethnic identity, and no additional measures capturing component parts of ethnicity (e.g., connectedness to the ethnic community, language used with peers, or level of familism) are available in the census.

As well, there are limitations with national social surveys, even those with a focus on family processes. Cycle 10 (1995) of the Canadian General Social Survey, which had "the family" as its core content area, included for the first time a question on home returning. However, sub-group sizes of young adults by ethnicity are too small for analyses beyond English, French and "other" (see Mitchell et al., 2000). Also, questions on returning in the 1995 GSS were not asked to all respondents who had already left home. Finally, Goldscheider and Goldscheider's $(1988 ; 1999)$ research provides valuable data on home leaving and home returning trajectories in the U.S., but generalizability to ethnic groups in Canada is tenuous. 
Home Leaving Trajectories in Canada: Exploring Cultural and Gender Dimensions

Given these gaps in the literature, resulting in large part from data limitations, the primary purpose of this paper is to provide a descriptive overview of the ethnocultural and gendered aspects of home leaving, home returning, and home staying based on a Vancouver-based study (the Culture and Coresidence Study) specifically designed for this purpose (see Methods for details). The four ethnocultural groups selected for this study are Canadian young adults of British, Chinese, Indian sub-continent, and South European origins. These groups were chosen on the basis of their relative diversity and because they are some of the most common ethnic groups in Canada and, in particular, the province of B.C.

While British have been, and still are, the major ethnic group within B.C., rapid immigration from Asian countries, in particular Hong Kong, China, and India (and other countries of the sub-continent) has contributed to a major shift in the ethnic composition of British Columbians (B.C. Stats, 2002). A closer examination of home staying, home leaving and home returning, therefore, needs to incorporate ethnocultural variation, which will be of interest to a wide variety of researchers and students studying the social demography of family life and ethnicity.

\section{Life Course Theoretical Frame}

The life course theoretical perspective is a multidisciplinary approach that is well-suited to the study of individual lives within family and structural contexts, as well as amidst social and economic change (Elder, 1985; Hagestad, 1990). Although the present research is exploratory, we employ a life course theoretical framework to help understand how household living arrangements - embedded within a specific socio-historical time period and geographical location - are formed over the life course, and are shaped (and reshaped) by cultural factors (e.g., norms, values, and traditions) (Hareven, 1996). As a concept, the life course is defined as "a sequence of socially defined events and roles that the individual enacts over time" (Giele and Elder, 1998:22). Age-related transitions are held to be "socially created, socially recognized, and shared" (Hagestad and Neugarten, 1985:35). Our particular focus is on the connections between cultural background and the timing and pathways of home leaving, (including the transition reversal of returning home).

It is generally acknowledged that within industrialized societies, individual biographies are becoming more individualistic in that young adults have more free choice about their own family-related behaviour, such as when to leave home and when to form a partnership (Lesthaeghe, 1995). At the same time, the life course perspective embodies the notion of heterogeneity in life course 
Ellen M. Gee, Barbara A. Mitchell and Andrew V. Wister

events. One important source of life course variation is culture; it is recognized that "cultural scripts" can affect the timing, duration, and sequencing of important life events (Elder, 1978, 1985; Hagestad and Neugarten, 1985). While considerable diversity exists within ethnic groups, it is generally assumed that cultural membership can shape expectations and decisions regarding home leaving. Cultural groups create and reproduce their own "social timetables." These timetables represent a normative schedule for key life course events, providing individuals and families with social and cognitive "road-maps" to guide life course decisions (Hagestad and Neugaarten, 1985). To avoid negative social sanctions, individuals adhere to their cultural group's expectations pertaining to when, and under what circumstances, they should make transitions.

As such, ethnocultural environments perpetuate unique social timetables that specify expectations about the "appropriate" timing and pathways under which young adults leave the parental home. Young adults from more familistic cultural backgrounds (e.g., Asians and South Europeans) are anticipated to leave home for marriage, school, or for employment - reasons that translate into later ages at leaving home and fewer returns after an initial departure, especially among those who leave to marry and begin family building. Conversely, young adults from more individualistic cultural backgrounds (e.g., British) may be more inclined to leave home to achieve "independence," (often coupled with work or school) rather than for family-centred reasons (e.g, to marry). Leaving home for these reasons would likely result in younger ages at home leaving and a higher proclivity for a subsequent return home because of an "incomplete" launch.

In this manner, ethnic culture helps to mould the reasons for and timing of home leaving, which in turn influence other living arrangement transitions and their stability. Furthermore, it is important to consider differences between young men and young women; social timetables can vary by both gender and ethnicity (Goldscheider and Goldscheider, 1999). For example, some cultural prescriptions regarding "proper" home leaving may be more restrictive for young women than for young men. This paper provides an exploratory investigation into these ethnocultural-youth transition relationships.

\section{Data and Methods}

\section{Sampling}

The data here are taken from a study (the Culture and Coresidence study) involving a survey of 1,907 young adults (ages 19-35) residing in the Greater Vancouver area conducted in 1999 and 2000. Young adults had to self-identify 
Home Leaving Trajectories in Canada: Exploring Cultural and Gender Dimensions

with one of four targeted ethnocultural groups -- British, Chinese, Indian or Southern-European origin -- based on responses to the question, "To which ethnic group do you most closely identify?" The British group consists of persons who self-identify as English, Scottish, Irish or Welsh (or any combination); the Chinese group consists of persons with origins in Hong Kong, Taiwan, and Mainland China; the Indian group contains individuals of Indian, Pakistani, or Sri Lankan backgrounds; and the South European group consists of persons of Greek, Italian, Spanish and Portuguese origins (the latter two groups including persons of Latin American heritages). While we recognize that none of these four groups is homogeneous, they do form distinctive groups on the basis of historical familial/kinship patterns.

The sample was obtained through two random sampling techniques. The majority of respondents $(90 \%)$ were obtained through randomly sampling a purchased list of Greater Vancouver household telephone numbers (with subfiles of Chinese and Indian surnames), in combination with Greek, Italian, and Chinese ethnic directories. A further $10 \%$ of respondents were obtained using a random digit dialling process. Trained interviewers used a CATI system for contacting, callbacks, screening, and the telephone-based interviews. Many of the interviewers were bi or multi-lingual in English and Cantonese and Mandarin, and in English and the languages of India. ${ }^{2}$ Approximately $8 \%$ (or 76) of the Chinese and Indo-Canadian interviews were conducted in the interviewee's home language. However, this figure underestimates the importance of interviewers with multiple-language proficiency, since if another household member who answered the telephone was unable to speak English, the interviewer's ability to communicate increased the likelihood of contact with an eligible household member. The response rate is $51 \%$, after eliminating all non-eligibles - persons who did not meet age and ethnocultural identification criteria.

Overall, the sample consists of $790(41.4 \%)$ men and $1,170(58.6 \%)$ women between the ages of 19 and 35, inclusive (see Table 1). Our target of at least 450 persons in each ethnocultural group was met - with 502 respondents of British origin, 462 of Chinese origin, 487 of Indian origin, and 456 of South European origin - thus ensuring approximately equal percentages of each group in the overall sample. The mean age of the total sample is 26.5 years. Despite the random sampling techniques used, the Chinese origin sample is slightly, but statistically significantly younger (mean age of 25.2 years) than the other three groups, a fact that must be kept in mind in across-group comparisons. It is also possible that some young adults, in particular those of Chinese origin, are temporarily living in Canada and may be unique to this study. However, these represent a small number of subjects and were therefore left in the analysis. 
Ellen M. Gee, Barbara A. Mitchell and Andrew V. Wister

\section{Interviews}

The research instrument is a structured interview, ${ }^{3}$ consisting of three versions depending on the home leaving trajectory of respondents, i.e., home stayers, home returners, or homeleavers. Respondents were asked a number of questions related to their home leaving category, their relationship with parents and exchanges of support, their ethnocultural identity and membership, attitudes about family life and gender roles, etc. While many questions were identical, including a set of background demographic questions, unique questions were asked of the different home leaving groups. All interviews were conducted by telephone, in the preferred language of the respondent, and ranged from 35-55 minutes in duration. All interviewees were assured of confidentiality and anonymity, and were informed that they could discontinue the interview at any time and/or not answer any question that made them feel uncomfortable.

\section{Measurement}

The main variables of interest are home leaving trajectory and ethnocultural category. Home leaving trajectory consists of three categories. Homeleavers are persons who have left their household/family of origin (for at least four months) and have never returned; home returners (or boomerangers) are those who have left home for at least four months and returned for at least four months at least once; ${ }^{4}$ and home stayers are persons who have never left their household/family of origin. It is important to note that these three categories are not synonymous with current living arrangement, although there is some overlap with it. This is particularly true for the home returners - this category includes both adult children who are currently living with their parents (current boomerangers) and those who were previously home returners and are not currently living with their parents. Also, home stayers may be living with their parents, living with their parents and others or living with a grandparent only, etc. - depending on the living arrangement in which they grew up. ${ }^{5}$ Respondents were placed into one of these categories based on a series of questions asking if they were living with the family members which whom they grew up, if they had left home and returned, and, if they had returned, for how long and how many times. Ethnocultural group has already been described as measured in terms of the individual's sense of identity/identification.

Measurement of the other variables is straightforward. Respondents were asked their age at certain events (e.g., age at first/only home leaving, age at first home return), and means were calculated. Reasons for home leaving, home returns and home staying were asked in an open-ended fashion (a list of reasons was not read to interviewees), with responses initially placed into pre-set categories by the interviewers or added if they did not fit into a category. In some cases, (e.g., 
Home Leaving Trajectories in Canada: Exploring Cultural and Gender Dimensions

financial reasons) responses were later aggregated by the researchers. Further, boomerangers were asked the number of times they had returned home (for a period of at least four months after a stay away of at least four months), and the duration (in months) of period(s) away from home. We also included the perceptions of reasons for a home leave among stayers.

Table 1

Characteristics of Sample

\begin{tabular}{lcccc}
\hline Characteristics & Number & $\begin{array}{c}\text { Percent of } \\
\text { Sample }\end{array}$ & $\begin{array}{c}\text { Percent } \\
\text { Female }\end{array}$ & Mean Age \\
\hline $\begin{array}{l}\text { British-Canadian } \\
\quad \text { Male }\end{array}$ & 502 & 26.3 & 60.8 & 27.2 \\
$\quad$ Female & 197 & & & 26.9 \\
Chinese-Canadian & 405 & & & 27.5 \\
$\quad$ Male & 208 & 24.2 & 55.0 & 25.2 \\
$\quad$ Female & 254 & & & 24.8 \\
& & & & 25.6 \\
Indo-Canadian & 487 & 25.5 & 65.9 & 27.1 \\
$\quad$ Male & 166 & & & 26.9 \\
$\quad$ Female & 321 & & & 27.1 \\
& & & & \\
South-European & & & & 26.3 \\
Canadians & 456 & 23.9 & & 26.6 \\
$\quad$ Male & 219 & & & 26.0 \\
$\quad$ Female & 237 & & & 26.5 \\
Total & & & & \\
$\quad$ Male & 1907 & 99.9 & & \\
$\quad$ Female & 790 & & & \\
& 1117 & & & \\
\hline
\end{tabular}

The data analysis techniques used are exploratory and serve to provide a profile of home leaving trajectories across the selected ethnocultural groups. For all variables, cross-tabulations are presented, with comparisons made across the four ethnocultural groups and by gender. For continuous variables, t-tests and analysis of variance techniques are conducted; for categorical variables, chi- 
Ellen M. Gee, Barbara A. Mitchell and Andrew V. Wister

square tests are calculated. Tests of significance are not performed when cell sizes are too small for reliable results. It is recognized that, since these data are cross-sectional, there is the potential for variant risk exposures for the home leaving trajectories across groups, which may influence the accuracy of the percentages. The small age differences across ethnic groups mitigate this problem.

\section{Results}

\section{Home Leaving Trajectories}

The initial analysis examines the three home leaving groups across the four ethnic groups and by gender. The total chi-square and the chi-square statistics for males and females are all statistically significant. As shown in Table 2, the four ethnocultural groups have strikingly different home leaving trajectories. There is a much higher percentage of homeleavers among British-Canadian young adults $(57.4 \%$ and $64.9 \%$ for males and females, respectively) than the others, with the exception of Indo-Canadian young women (67.6\%). Nearly onehalf of the South European-Canadian young adults are home leavers. For both European-origin groups, there is no significant gender difference in the percentage that is home leavers. In contrast, gender differences in home leaving between the two Asian-origin groups are large, especially for the Indo-Canadian group, where it is observed that male young adults are more than twice as likely as their female counterparts to have left home.

Home returning is most common among the British-Canadians $(24.4 \%$ of the young adult males and $23 \%$ of the females are "boomerangers") and least common among Indo-Canadian young adults $(15.1 \%$ for men and $5.3 \%$ for women). In contrast, home staying is least prevalent among British-Canadians (18.3\% among male young adults and $12.1 \%$ among females). More than onethird of the South European-Canadians are home stayers - 35.6\% and 36.3\%, respectively, for male and female young adults. With these two groups, gender differences are small. However, among the Chinese-Canadians, $47.2 \%$ of young men and $37.7 \%$ of young women are home stayers (but it must be kept in mind that this group is about one year younger than the other three). Among the IndoCanadians, $54 \%$ of men are home stayers, while young women are one-half as likely $(27 \%)$ to be living at home at the time of the survey - less than the other groups of women except for the British. 
Home Leaving Trajectories in Canada:

Exploring Cultural and Gender Dimensions

\section{Home Leavers}

Table 3 presents the mean ages at leaving home for home leavers (by gender), which provides an estimate of the timing of this transition. Ethnocultural differences in age at home leaving are statistically significant, both among males and females. Among men, this difference can be largely accounted for by a much later age at home leaving (23.0) among Indo-Canadian young men. IndoCanadian women also leave home later than their gender peers, but they are followed quite closely by Chinese-Canadian women. The British-origin men and women leave home at the youngest ages, just over 19. Chinese-Canadian appear to be anomalous in that they leave home at younger ages than might be expected of members of an ethnocultural group well known for its familistic orientation. Only the Chinese show a within-ethnic group gender difference, with young men leaving home at younger ages than young women - 19.4 years vs. 21.6 years.

As observed in Table 4, the reasons for home leaving differ widely across ethnocultural groups, and by gender, with statistically significant differences across ethnic groups observed for the total, as well as for males and females. Chinese-Canadian young adults are far more likely $(62.8 \%$ of females and $40.8 \%$ of males) to leave home to go to school than are their counterparts in the other groups. Leaving home to obtain independence is common among the two European-origin groups, where it can be seen that $45.1 \%$ of British-Canadians and $46.2 \%$ of South European-Canadian male young adults do so. In contrast, leaving home to form a union (marriage/cohabitation) is by far the most important reason among Indo-Canadians - $87.6 \%$ of women and $36.5 \%$ of men leave for this reason. In contrast, only $6.2 \%$ of British-origin men and $20.2 \%$ of British-origin women leave home to form a union. Leaving home for work reasons does not figure prominently for any of the groups, nor does leaving due to conflict at home. Thus, for three of the groups, there is one dominant reason for home leaving - for British-Canadians, it is to achieve independence; for Chinese-Canadians, it is to attend school; and for Indo-Canadians, it is to get married. Among the South European-Canadians, a mixed pattern exists: for female young adults, forming a union is the most important reason, cited by $43.9 \%$ of the sample; for males, it is seeking independence (46.2\%).

Despite the existence of a major (and different) reason for home leaving across ethnocultural groups, significant gender differences remain. Among BritishCanadians, young men are more likely to seek independence and young women are more likely to leave home to form a union. Among Chinese-Canadians, young men are more likely to leave for schooling and young women are more likely to leave home to marry. As noted above, among South EuropeanCanadians, union formation is the most important reason for women; for men it 
is seeking independence. In contrast, both male and female Indo-Canadians tend to leave home to get married; however, there is considerably more variability in the reasons cited among Indo-Canadian young men than among Indo-Canadian young women.

Table 2

Percent Distribution of Home leaving Trajectory by Ethnic Origin and Gender

\begin{tabular}{lcccccccc}
\hline & \multicolumn{2}{c}{ British } & \multicolumn{2}{c}{ Chinese } & \multicolumn{2}{c}{ Indian } & \multicolumn{3}{c}{$\begin{array}{c}\text { South } \\
\text { European }\end{array}$} \\
& M & F & M & $\mathbf{F}^{*}$ & M & $\mathbf{F}^{*}$ & M & F \\
\hline Homeleavers & 57.4 & 64.9 & 33.7 & 47.2 & 31.3 & 67.6 & 48.4 & 48.1 \\
Returners & 24.4 & 23.0 & 19.2 & 15.8 & 15.1 & 5.3 & 16.0 & 15.6 \\
Home stayers & 18.3 & 12.1 & 47.1 & 37.0 & 53.6 & 27.1 & 35.6 & 36.3 \\
\multicolumn{1}{c}{$\mathbf{n}$} & 197 & 305 & 208 & 254 & 166 & 321 & 219 & 237 \\
\hline
\end{tabular}

*chi-square (gender) is signfiicant at less than the .05 level

chi-square $($ total $)=122.53, \mathrm{p}<.001$

chi-square $($ males $)=61.38, \mathrm{p}<.001$

chi-square $($ females $=92.07, \mathrm{p}<.001$

\section{Home Returners}

It is also useful to examine (separately) the home leaving patterns of home returners, in order to establish the connections between these transitions. The mean age at (first) home leaving for home returners are shown in Table 5. The most salient finding is that, compared with homeleavers (Table 3), home returners leave home at younger ages among all four ethnocultural groups. There are remarkably few differences across ethnocultural and gender groups in age at home leaving among boomerangers - all left home between 18 and 19 (except Indo-Canadian young women, who left home at 21.1 years of age). 
Home Leaving Trajectories in Canada:

Exploring Cultural and Gender Dimensions

Table 3

Mean Age at (First) Home leaving by Ethnic Origin and Gender: Home Leavers

\begin{tabular}{lcccc}
\hline \multicolumn{1}{l}{ Ethnic Origin } & Males & \multicolumn{2}{c}{ Females } \\
\hline British & 19.2 & $(113)$ & 19.1 & $(198)$ \\
Chinese* & 19.4 & $(69)$ & 21.6 & $(120)$ \\
Indian & 23.0 & $(52)$ & 22.2 & $(217)$ \\
South European & 21.5 & $(106)$ & 20.8 & $(112)$ \\
\hline
\end{tabular}

\footnotetext{
*t-test (gender) is signfiicant at less than the .05 level

$\mathrm{F}($ total $)=41.26, \mathrm{p}<.001$

$\mathrm{F}($ males $)=16.92, \mathrm{p}<.001$

$\mathrm{F}($ females $=31.79, \mathrm{p}<.001$
}

Reasons for leaving home the first time for home returners, however, vary quite widely across the ethnocultural groups (see Table 6). Among ChineseCanadians, schooling is predominant, with $65 \%$ of both young men and young women initially leaving home to go to school. The other three groups display more variation in reasons for home leaving. For the British and South Europeans - both male and females - leaving home for school and for independence are important, together accounting for about one-half of reasons. For IndoCanadian males, the most important reasons are work $(36 \%)$ and schooling $(32 \%)$; for Indo-Canadian females, they are to marry $(41.2 \%)$ and to pursue schooling $(23.5 \%)$. Leaving home to attend school is an important reason for all home returners. Except for Chinese-Canadians, it is a more important reason for home leaving among the home returner group than for the home leaver group (shown in Table 4). Together, the data in Tables 5 and 6 tell us that boomerangers (with the exception of Indo-Canadian women) are more likely to leave home at a relatively early age in order to attend school.

The duration (in months) of the first period away from home is presented in Table 7, showing a statistically significant difference overall. Returners were away from home for at least one and one-half years (with the exception of 
British-origin males). ${ }^{6}$ The two European-origin groups stayed away a shorter period of time than the two Asian-origin groups, in keeping with their greater tendency to leave home for independence. The mean durations are not significantly different for the young women across the four ethnic groups; for men, a statistically significant difference can be accounted for by the comparatively short durations of British-Canadians in contrast to the long durations of Chinese-Canadians.

Table 4

Percent Distribution of Main Reason for Leaving Home by Gender: Home Leavers

\begin{tabular}{|c|c|c|c|c|c|c|c|c|}
\hline \multirow{2}{*}{$\begin{array}{c}\text { Main } \\
\text { Reason }\end{array}$} & \multicolumn{2}{|c|}{ British* } & \multicolumn{2}{|c|}{ Chinese* } & \multicolumn{2}{|c|}{ Indian } & \multicolumn{2}{|c|}{$\begin{array}{c}\text { South } \\
\text { European* }\end{array}$} \\
\hline & $\mathbf{M}$ & $\mathbf{F}$ & M & $\mathbf{F}$ & $\mathbf{M}$ & $\mathbf{F}$ & $\mathbf{M}$ & $\mathbf{F}$ \\
\hline School & 20.4 & 24.2 & 62.8 & 40.8 & 17.1 & 1.4 & 9.4 & 11.4 \\
\hline Work & 12.4 & 7.1 & 7.1 & 5.8 & 17.3 & 5.0 & 13.2 & 5.3 \\
\hline Independence & 45.1 & 33.8 & 14.3 & 9.2 & 19.2 & 2.8 & 46.2 & 28.1 \\
\hline Marry/cohabit & 6.2 & 20.2 & 7.1 & 36.7 & 36.5 & 87.6 & 27.4 & 43.9 \\
\hline Conflict at home & 7.1 & 7.6 & 1.4 & 0.8 & 3.9 & 0.0 & 2.8 & 7.9 \\
\hline Other & 8.9 & 7.1 & 7.1 & 6.7 & 5.8 & 3.2 & 1.0 & 3.5 \\
\hline $\mathbf{n}$ & 113 & 198 & 70 & 120 & 52 & 217 & 106 & 114 \\
\hline
\end{tabular}

*chi-square (gender) is signfiicant at less than the .05 level chi-square $($ total $)=392.75, \mathrm{p}<.001$

chi-square $($ males $)=27.83, \mathrm{p}<.001$

chi-square (females $=47.93, \mathrm{p}<.001$ 
Home Leaving Trajectories in Canada:

Exploring Cultural and Gender Dimensions

Table 5

Mean Age at (First) Home leaving by Ethnic Origin and Gender:

Returners

\begin{tabular}{lcccc}
\hline \multicolumn{1}{c}{ Ethnic Origin } & \multicolumn{3}{c}{ Females } \\
\hline British & 18.8 & $(48)$ & 18.4 & $(70)$ \\
Chinese & 18.2 & $(40)$ & 18.5 & $(46)$ \\
Indo-Canadian & 19.0 & $(25)$ & 21.1 & $(17)$ \\
South European & 18.5 & $(35)$ & 18.7 & $(37)$ \\
\hline
\end{tabular}

$\mathrm{F}($ total $)=5.29, \mathrm{p}<.01$

$\mathrm{F}($ males $)=2.07,(\mathrm{~ns})$

$\mathrm{F}($ females $=3.91, \mathrm{p}<.01$

Data on reasons for returning home are shown in Table 8. Interestingly, only the European-origin groups (about one-third) cite financial reasons (financial problems plus to save money) as a main reason for a return. "Transitional" reasons - which include finished traveling, school or work; temporary until job/school starts or until accommodation available; waiting until married; no other place to go; and waiting for visa/immigration status, are important for all groups, with Indo-Canadians most likely to state the last reason. "Other reasons" (especially that of "reunited in the same city") are very important for the two Asian-origin groups, which suggests that there are some important international migration patterns occurring.

\section{Home Stayers}

Financial reasons appear to be the most important reason for remaining at home among the British, South European, and Chinese-origin groups (see Table 10). For British-Canadian young adults, $66.7 \%$ of men and $55.4 \%$ of women provide financial reasons for staying. The percentages for young adults of South European origin are $51.3 \%$ (men) and 40.4\% (women); and for ChineseCanadians, $37.8 \%$ (men) and $35.1 \%$ (women). In contrast, most (71.9\%) Indo- 
Table 6

Percent Distribution of Main Reason for Leaving Home First Time by Ethnic Origin and Gender: Returners

\begin{tabular}{|c|c|c|c|c|c|c|c|c|}
\hline \multirow{2}{*}{$\begin{array}{c}\text { Main } \\
\text { Reason }\end{array}$} & \multicolumn{2}{|c|}{ British } & \multicolumn{2}{|c|}{ Chinese } & \multicolumn{2}{|c|}{ Indian } & \multicolumn{2}{|c|}{$\begin{array}{c}\text { South } \\
\text { European }\end{array}$} \\
\hline & $\mathbf{M}$ & $\mathbf{F}$ & $\mathbf{M}$ & $\mathbf{F}$ & $\mathbf{M}$ & $\mathbf{F}$ & M & $\mathbf{F}$ \\
\hline School & 31.3 & 34.3 & 65.0 & 65.0 & 32.0 & 23.5 & 22.9 & 27.0 \\
\hline Work & 14.6 & 10.0 & 12.5 & 22.5 & 36.0 & 17.7 & 20.0 & 8.1 \\
\hline Independence & 22.9 & 25.7 & 10.0 & 0.0 & 12.0 & 5.9 & 34.3 & 24.3 \\
\hline Marry/cohabit & 8.3 & 10.0 & 2.5 & 7.5 & 8.0 & 41.2 & 5.7 & 8.1 \\
\hline Conflict at home & 12.5 & 12.9 & 2.5 & 2.5 & 4.0 & 5.9 & 11.4 & 18.9 \\
\hline Other & 10.4 & 7.1 & 7.5 & 2.5 & 8.0 & 5.9 & 5.7 & 13.5 \\
\hline $\mathbf{n}$ & 48 & 70 & 40 & 40 & 25 & 17 & 35 & 37 \\
\hline
\end{tabular}

chi-square $($ total $)=60.70, \mathrm{p}<.001$

chi-square $($ males $)=27.83, \mathrm{p}<.05$

chi-square $($ females $=47.93, \mathrm{p}<.001$

Canadian young adult men report closeness to parents as the reason for staying; whereas for Indo-Canadian women, the main reasons are culture/tradition $(38 \%)$ followed by closeness to parents $(31 \%)$, and financial reasons $(24.1 \%)$. Staying home because of continued schooling surfaced as the secondary most common reason for British-Canadian and South European-Canadian young adults and for Chinese-Canadian young men.

When asked what the main reason would be for leaving home among those who have not yet left, some interesting patterns emerge. Table 11 shows that a majority of young adults of British origin (69.4\% men and 37\% women) and of the South European-origin (50\% men and 46.5\% women) identify financial reasons as being the likely reason for nest leaving. Young women of Chinese and Indo-Canadian origins state marriage as the most likely reason to leave 
Home Leaving Trajectories in Canada: Exploring Cultural and Gender Dimensions

home $(44.7 \%$ and $56.3 \%$, respectively). For Chinese-Canadian young men, financial reasons $(29.6 \%)$, marriage $(22.5 \%)$ and other reasons $(21.4 \%)$ are the most commonly reported reasons. Among Indo-Canadian males, most $(55.1 \%)$ stated that they could not conceive of a reason for leaving home; that is, they expected never to leave.

Table 7

Duration (in Months) of First Period Away from Home by Ethnic Origin and Gender: Returners

\begin{tabular}{|c|c|c|}
\hline Ethnic Origin & $\mathbf{N}$ & Mean \\
\hline \multicolumn{3}{|l|}{ British } \\
\hline Males & 48 & 15.4 \\
\hline Females & 70 & 20.3 \\
\hline \multicolumn{3}{|l|}{ Chinese } \\
\hline Males & 40 & 32.1 \\
\hline Females & 40 & 26.3 \\
\hline \multicolumn{3}{|l|}{ Indo-Canadian } \\
\hline Males & 25 & 27.8 \\
\hline Females & 17 & 24.1 \\
\hline \multicolumn{3}{|l|}{ South European } \\
\hline Males & 35 & 21.0 \\
\hline Females & 37 & 18.3 \\
\hline
\end{tabular}

$\mathrm{F}($ total $)=4.95, \mathrm{p}<.01$

$\mathrm{F}($ males $)=5.23, \mathrm{p}<.01$

$\mathrm{F}($ females $)=1.01,(\mathrm{~ns})$ 
Ellen M. Gee, Barbara A. Mitchell and Andrew V. Wister

Table 8

Percent Distribution of Number of Tmes Left Home and Returned by Ethnic Origin and Gender

\begin{tabular}{|c|c|c|c|c|c|c|c|c|}
\hline \multirow{2}{*}{$\begin{array}{l}\text { Number of } \\
\text { Times Left } \\
\text { Hoime }\end{array}$} & \multicolumn{2}{|c|}{ British } & \multicolumn{2}{|c|}{ Chinese } & \multicolumn{2}{|c|}{ Indian } & \multicolumn{2}{|c|}{$\begin{array}{c}\text { South } \\
\text { European }\end{array}$} \\
\hline & $\mathbf{M}$ & $\mathbf{F}$ & $\mathbf{M}$ & $\mathbf{F}$ & $\mathbf{M}$ & $\mathbf{F}$ & $\mathbf{M}$ & $\mathbf{F}$ \\
\hline 1 & 50.0 & 57.1 & 62.5 & 77.5 & 68.0 & 70.6 & 51.4 & 46.0 \\
\hline 2 & 27.1 & 17.1 & 17.5 & 10.0 & 16.0 & 23.5 & 28.6 & 32.4 \\
\hline $3+$ & 22.9 & 25.7 & 20.0 & 12.5 & 16.0 & 5.9 & 20.0 & 21.6 \\
\hline $\mathbf{n}$ & 48 & 70 & 40 & 40 & 25 & 17 & 35 & 37 \\
\hline
\end{tabular}

\section{Discussion}

This exploratory study represents an important first step in elaborating the linkages among cultural background, social timetables, home leaving trajectories, and the living arrangements of Canadian young adults. We document in this paper striking ethnocultural, as well as gender, differences in home leaving trajectories among Canadian young adults living in Greater Vancouver. At a broad level, many of these patterns relate to whether a young adult identifies with a European (British or South European) or Asian (Chinese or Indo-Canadian) cultural background, although there are a number of substantive differences between (by ethnicity and gender) and within (by gender) each of the groups comprising this east-west dichotomy.

Generally, European-origin young adults tend to be homeleavers and to leave home to achieve "independence," compared to the Asian-origin groups. They are also more likely to have returned home as "boomerang kids," to do so after shorter durations, and to be more likely to have done so multiple times. European-origin young adults are also more likely to report returning home for financial rather than non-financial reasons (about one-third site this as a main reason). A propensity is also demonstrated for them to report a financial reason 
Home Leaving Trajectories in Canada: Exploring Cultural and Gender Dimensions

for staying home, as well as predict that this will be an important factor in their inevitable launch. These patterns indicate that the British, and to a lesser degree South European-origin young adults, exhibit home leaving trajectories that are more volatile, and reflective of a more permissive cultural milieu than the Asian-origin groups. The European-origin groups clearly experience more transition reversals (i.e., boomerangs). Earlier research suggests that multiple returners are problematic for parent/child relations (Mitchell and Gee, 1996), an issue that families of European origin are more likely to face. Furthermore, common, media-perpetuated beliefs that boomerang kids return home mainly because of a poor economic climate is not strongly supported. In fact, this is only one of several of reasons; however, financial reasons appear to be important for staying at home and perceived as an important future reason for a departure.

Table 9

Percent Distribution of Reason for Returning Home the First and Second Time by Ethnic Origin: Returners

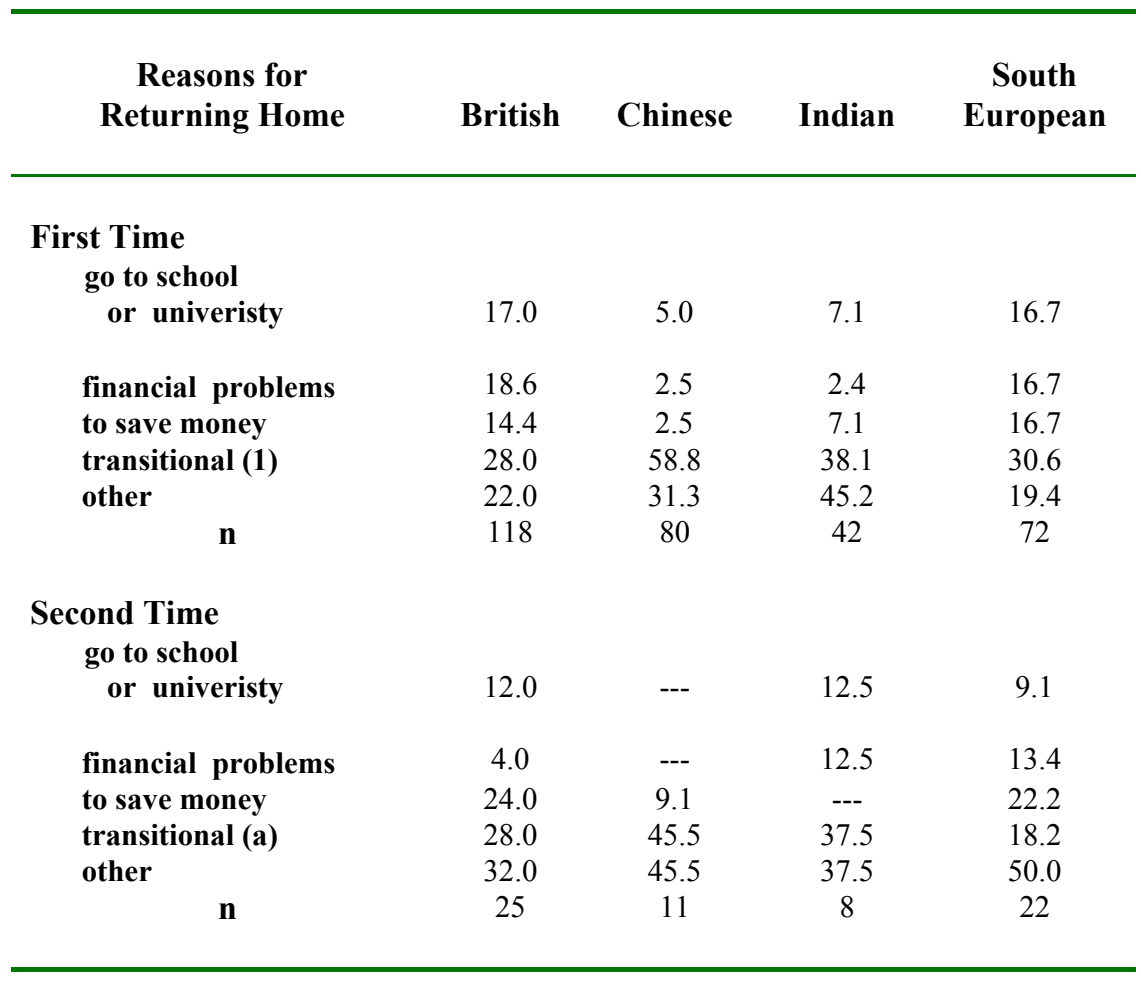


Ellen M. Gee, Barbara A. Mitchell and Andrew V. Wister

Table 10

Percent Distribution of Main Reason for Remaining Home by Ethnic Origin and Gender: Home Stayers

\begin{tabular}{|c|c|c|c|c|c|c|c|c|}
\hline \multirow{2}{*}{$\begin{array}{c}\text { Main } \\
\text { Reasons }\end{array}$} & \multicolumn{2}{|c|}{ British } & \multicolumn{2}{|c|}{ Chinese* } & \multicolumn{2}{|c|}{ Indian } & \multicolumn{2}{|c|}{$\begin{array}{c}\text { South } \\
\text { European }\end{array}$} \\
\hline & $\mathbf{M}$ & $\mathbf{F}$ & $\mathbf{M}$ & $\mathbf{F}$ & $\mathbf{M}$ & $\mathbf{F}$ & M & $\mathbf{F}$ \\
\hline Financial & 66.7 & 51.4 & 37.8 & 35.1 & 9.0 & 24.1 & 51.3 & 40.7 \\
\hline Schooling & 19.4 & 27.0 & 22.5 & 11.7 & 3.4 & 2.3 & 16.8 & 27.9 \\
\hline Close to parents & 8.3 & 13.5 & 10.2 & 19.2 & 71.9 & 31.0 & 14.1 & 12.8 \\
\hline $\begin{array}{l}\text { Cultural/ } \\
\text { Traditional }\end{array}$ & 2.8 & 2.7 & 13.3 & 23.4 & 9.0 & 38.0 & 12.8 & 12.8 \\
\hline Other & 2.8 & 5.4 & 16.3 & 10.6 & 6.7 & 4.6 & 5.1 & 5.8 \\
\hline $\mathbf{n}$ & 36 & 37 & 98 & 94 & 89 & 87 & 78 & 86 \\
\hline
\end{tabular}

*chi-square (gender) is significant at leass than .05 level

chi-square (total) 161.49, $\mathrm{p}<.001$

chi-square $($ males $)=136.30, \mathrm{p}<.001$

chi-square $($ females $=59.68, \mathrm{p}<.001$

The two Asian-origin groups tend to leave home later, return less often and after longer periods of time, and exhibit fewer multiple returns. Asian-origin young adults are less likely than European-origin young adults to state that they live at home for financial reasons, or return for these reasons. Ethnocultural differences between the two Asian groups are also apparent, particularly for transitional reasons. For example, Chinese-Canadian young adults tend to leave home for schooling, whereas Indo-Canadian young adults leave for marriage, (which is often arranged). ${ }^{7}$ With regard to reasons for staying at home, Indo-Canadian young adults, in particular, tend to state that they live with their parents due to a cultural tradition or because they are close to their parents. Thus, it can be suggested that Chinese-Canadian exceptionalism in educational attainment and the values undergirding it play a more important role than familistic tradition in affecting the timing of home leaving, a factor more influential among IndoCanadian young adults. 
Home Leaving Trajectories in Canada:

Exploring Cultural and Gender Dimensions

Table 11

Percent Distribution of Main Reason for Leaving Home (in Future) by Ethnic Origin and Gender: Home Stayers

\begin{tabular}{|c|c|c|c|c|c|c|c|c|}
\hline \multirow{2}{*}{$\begin{array}{c}\text { Main } \\
\text { Reasons }\end{array}$} & \multicolumn{2}{|c|}{ British } & \multicolumn{2}{|c|}{ Chinese* } & \multicolumn{2}{|c|}{ Indian* } & \multicolumn{2}{|c|}{$\begin{array}{c}\text { South } \\
\text { European }\end{array}$} \\
\hline & $\mathbf{M}$ & $\mathbf{F}$ & $\mathbf{M}$ & $\mathbf{F}$ & $\mathbf{M}$ & $\mathbf{F}$ & $\mathbf{M}$ & $\mathbf{F}$ \\
\hline school-related $* *$ & 11.1 & 35.1 & 12.2 & 11.7 & 2.3 & 8.1 & 9.0 & 7.0 \\
\hline financially able & 69.4 & 37.8 & 29.6 & 25.3 & 18.0 & 18.0 & 50.0 & 46.5 \\
\hline marry/cohabit & 8.3 & 16.2 & 22.5 & 44.7 & 13.5 & 56.3 & 29.2 & 36.1 \\
\hline independence & 8.3 & 5.4 & 11.2 & 6.4 & 1.1 & 1.2 & 7.7 & 2.3 \\
\hline $\begin{array}{l}\text { no such } \\
\text { circumstance }\end{array}$ & 0.0 & 0.0 & 3.1 & 3.2 & 55.1 & 11.5 & $0 . .0$ & 2.3 \\
\hline other & 2.8 & 5.4 & 21.4 & 8.5 & 10.0 & 4.6 & 3.9 & 5.8 \\
\hline $\mathbf{n}$ & 36 & 37 & 98 & 94 & 89 & 87 & 78 & 86 \\
\hline
\end{tabular}

*chi-square (gender) is significant at leass than .05 level

**includes completing school or going elsewhere to school chi-square (total) 199.10, $\mathrm{p}<.001$

chi-square $($ males $)=165.67, \mathrm{p}<.001$

chi-square $($ females $=59.33, \mathrm{p}<.001$

There are also connections among the home leaving trajectories, although further research is needed on this topic. Home leaving timing and pathways among the boomerang group indicate that this group leaves home earlier and for more varied reasons that are also more prone to change, for example, independence, work, schooling and "other." This corresponds with previous research demonstrating that earlier ages of first home leaving are linked to a subsequent return home (Gee, Mitchell and Wister, 1995). Thus, there may be a disadvantage to some young adults who leave home early before they are fully "settled" in their work and family careers. 
Turning to gender differences, there are a number of variations in home leaving trajectories across gender within and between ethnocultural groups. Overall, greater differences are observed between young men and young women of Asian-origin than of European-origin. For example, Chinese-Canadian and IndoCanadian males are much more likely to leave home for school and to achieve independence compared to females, while females are much more likely to leave home when they get married. Yet some gender differences are observed for the European-origin groups as well. For example, British-origin females are also more likely to leave home for marriage or cohabitation than males, who predominantly leave home for independence. The proposition that gender differences in family behaviour have become attenuated for young Canadian adults (Meunier, Bernard and Boisjoly, 1999) does not hold for our Asian-origin population.

Taken together, these findings highlight how individual biographies embedded within family and cultural contexts in Canadian society are not necessarily following an increasingly individualized pattern, as suggested by many theorists such as Giddens (1991) and Beck (1992). Rather, it appears that ethnocultural membership influences home leaving processes in a variety of ways simultaneously, none of which are one-dimensional. This research lends support to the adoption of a life course perspective that recognizes cultural heterogeneity in the timing of and circumstances surrounding leaving the parental home. Specifically, our findings suggest that there are salient cultural differences in the age-linked expectations, sanctions, and options underlying "social timetables," which manifest as different patterns of home leaving, home staying and returning home.

\section{Limitations and Future Research}

This research has several limitations that raise important issues for future research. Given the exploratory, descriptive nature of the analyses, more sophisticated analytic strategies are required. In particular, we need to conduct life event history analysis in order to deal with differential risk exposure (through a censoring technique) and to include a more comprehensive set of independent variables (see Mitchell, Wister and Gee, 2003). Inclusion of a broader set of cultural measures (e.g., immigration history, religiosity, participation in ethnic-group related activities, language use) could also elucidate the mechanisms underlying the observed cultural effects. This could help to disentangle socio-economic effects (e.g., family income, education) from cultural factors. More attention also needs to be paid to diversity within a particular culture. Furthermore, interaction effects should also be investigated in 
Home Leaving Trajectories in Canada: Exploring Cultural and Gender Dimensions

order to examine interrelationships among variables.

Future data collection on this subject should also include a greater number of cultural groups. It is also important to recognize that many young adults identify with more than one cultural group because they are the children of intercultural unions. Inclusion of more direct questions on cultural norms, values and expectations would assist in understanding the mechanisms whereby cultural groups sustain and reinforce "traditional" or "modern" orientations that underly nestleaving expectations and behaviour.

In addition, more attention needs to be paid to migration patterns and geographical location. For example, in some ethnic groups, it appears that there is considerable transcontinental migration that causes temporary or permanent relocation that can significantly affect home leaving processes. Regional variation within Canada is also an important focus of study, since there may be provincial variations in home leaving due to differential access to education and labour market opportunities. It would also be fruitful to study rural and urban family strategies in the "launching" of children and to investigate differences among major cities.

Finally, much could be gained from conducting longitudinal research in order to examine the long-term implications of home leaving behaviour. For example, does leaving home to attain "independence" positively affect long-term wellbeing, and family, educational and career paths? What about those young adults who perceive that their home leaving trajectories are constrained, leaving them little choice? Do these situations negatively affect young adults and generate intergenerational conflict, or is the fulfillment of cultural expectations conducive to greater harmony? Ideally, researchers should triangulate data from qualitative and quantitative sources, including the perspectives of both generations, to more fully understand the complexity of home leaving trajectories and the cultural and gender dynamics underlying such patterns.

\section{Acknowledgements::}

Revised version of a paper presented at a joint session at the annual meetings of the Canadian Sociology and Anthropology Association and the Canadian Population Society, Laval University, Quebec City, 26-30 May, 2001. The authors acknowledge the support of the Social Sciences and Humanities Research Council of Canada, and the assistance of Doug Talling with computer runs. 


\section{End Notes:}

1. Eastern Europeans were not included due to the possibility that recent immigrants from that area would, due to the political instabilities preceding their move to Canada, have atypical family and home leaving circumstances.

2. We did not need interviewers with facility in any of the South European languages.

3. Some questions were less structured, with probes built in to elicit more qualitative data.

4. The four month criteria are commonly used by researchers in this field in order to exclude brief moves home, likely caused by temporary exigencies.

5. These categories are not static. For example, a homeleaver at the time of the survey could later become a home returner or a homeleaver; a homeleaver could become a boomeranger later on.

6. It should be remembered that we screened out returns of less than four months duration.

7. The prevalence of various kinds of arranged marriages among IndoCanadians was revealed in a semi-structured probe question.

\section{References}

Beck, U. 1992. Risk Society: Towards a New Modernity. Thousand Oaks, Calif.: Sage Publications.

Boyd, M. 2000. "Ethnic Variations in Young Adults Living at Home," Canadian Studies in Population 27(1):135-158.

Boyd, M. and D. Norris. 2000. "Demographic Change and Young Adults Living with Parents, 1981-1996," Canadian Studies in Population 27(2): 267-281. 
Home Leaving Trajectories in Canada: Exploring Cultural and Gender Dimensions

Boyd, M. and D. Norris. 1999. "The Crowded Nest: Young Adults at Home," Canadian Social Trends (Spring): 2-5.

B.C. Stats. 2001. http://www.bcstats.gov.bc.ca/data/cen91/issue 16.htm.

Elder, G.H., Jr. 1978. "Approaches to Social Change and the Family," American Journal of Sociology 84 (Suppl.): S1-S38.

Elder, G.H., Jr. 1985. (ed.) Life Course Dynamics, Trajectories and Transitions, 1968-1980. Ithaca, N.Y.: Cornell University Press.

Gee, E.M., B.A. Mitchell and A.V. Wister. 1995. "Returning to the Parental 'Nest': Exploring a Changing Canadian Life Course," Canadian Studies in Population 22(2):121-44.

Giddens, A. 1991. Modernity and Self-Identity. Self and Society in the Late Modern Age. California: Stanford University Press.

Giele, J.Z. and G.H. Elder, Jr. 1998. Methods of Life Course Research: Qualitative and Quantitative Approaches. Thousand Oaks, Calif.: Sage Publications.

Goldscheider, C. and F.K. Goldscheider. 1988. "Ethnicity, Religiosity and Leaving Home: The Structural and Cultural Bases of Traditional Family Values," Sociological Forum 3(4): 525-547.

Goldscheider, F.K. and C. Goldscheider. 1999. The Changing Transition to Adulthood: Leaving_and Returning Home. Thousand Oaks, Calif.: Sage Publications.

Hagestad, G.O. 1990. "Social Perspectives on the Life Course," in Handbook of Aging and the Social Sciences. R. Binstock and L. George, (eds.). New York: Academic. Pp. 151-68.

Hagestad, G.O. and B.L. Neugarten. 1985. "Age and the Life Course," in Handbook of Aging and the Social Sciences, R.H. Binstock and E. Shanas (eds.). New York: Van Nostrand Reinhold Co. Pp. 35-61.

Hareven, T. (ed.). 1996. Aging and Generational Relations: Life-course and Cross-Cultural Perspectives. New York: Aldine de Gruyter. 
Ellen M. Gee, Barbara A. Mitchell and Andrew V. Wister

Lesthaeghe, R. 1995. "The Second Demographic Transition: An Interpretation," in Gender and Family Change in Industrialized Countries, K.O. Mason and A.M. Jensen (eds.). Oxford: Clarendon Press. Pp. 17-62.

Meunier, D., P. Bernard and J. Boisjoly 1999 "Eternal Youth? Changes in the Living Arrangements of Young People in Canada" ESC Research Paper Series. Vancouver: University of British Columbia. www.arts.ubc.ca/cresp/resear.htm

Mitchell, B.A. and E.M. Gee. 1996. 'Boomerang Kids' and Midlife Parental Marital Satisfaction," Family Relations 45: 442-448.

Mitchell, B.A., A.V. Wister and E.M. Gee. 2003. "The Ethnic and Family Nexus of Home leaving and Home Returning among Canadian Young Adults." Paper to be presented at the annual Pacific Sociological Meetings, Pasedena, California, April.

Mitchell, B.A., A.V.Wister and E.M. Gee. 2000. "Culture and Coresidence: An Exploration of Variation in Home-Returning among Canadian Young Adults," Canadian Review of Sociology and Anthropology 37(2): 197-222.

Ravenera, Z., F. Rajulton and T.K. Burch. 1995. "A Cohort Analysis of Homeleaving in Canada," Journal of Comparative Family Studies 26, 2: 179193. 